floodplain system of the study area. While this partially meets water requirement for a part of North Delhi, it will avoid waterlogging.

1. Shekhar, S., An approximate projection of availability of the fresh groundwater resources in the South West district of NCT Delhi, India: a case study. Hydrogeol. J., 2006, 14(7), 1330-1338.

2. Chatterjee, R., Gupta, B. K., Mohiddin, S. K., Singh, P. N., Shekhar, S. and Purohit, R., Dynamic groundwater resources of National Capital Territory, Delhi: assessment, development and management options. Environ. Earth Sci., 2009, 59(3), 669-686.

3. Sarkar, A., Ali, S., Kumar, S., Shekhar, S. and Rao, S. V. N., Groundwater environment in Delhi, India. In Groundwater Environment in Asian Cities: Concepts, Methods and Case Studies, Butterworth-Heinemann, Elsevier, B.V., 2016, pp. 77108.

4. Shekhar, S. and Prasad, R. K., The groundwater in Yamuna flood plain of Delhi (India) and the management options. Hydrogeol. J., 2009, 17, 1557-1560.

5. Shekhar, S., An approach to interpretation of step drawdown tests. Hydrogeol. J., 2006, 14(6), 1018-1027.

6. Rao, S. V. N., Kumar, S., Shekhar, S., Sinha, S. K. and Manju, S., Optimal pumping from skimming wells from the Yamuna River flood plain in north India. Hydrogeol. J., 2007, 15, 1157-1167.

7. Kumar, S., Sarkar, A., Thakur, S. K. and Shekhar, S., Hydrogeological characterization of aquifer in palla flood plain of Delhi using integrated approach. J. Geol. Soc. India, 2017, 90(4), 459-466.

8. Shekhar, S., Mao, R. S. and Imchen, E. B., Groundwater management options in North district of Delhi, India: a groundwater surplus region in over-exploited aquifers. J. Hydrol.: Reg. Stud., 2015, 4, 212-226; http://dx.doi.org/10.1016/j.ejrh.2015.03.003

9. Soni, V., Shekhar, S., Rao, S. V., Kumar, S. and Singh, D., A new solution for city water: quality drinking water from the river floodplains. Curr. Sci., 2018, 114(3), 452-461.

10. Soni, V., Shekhar, S. and Singh, D., Environmental flow for the Yamuna river in Delhi as an example of monsoon rivers in India. Curr. Sci., 2014, 106(4), 558-564.

11. Karanth, K. R., Ground Water Assessment: Development and Management, Tata McGraw-Hill Education, New Delhi, 1987.

Received 20 November 2016; revised accepted 19 November 2018

doi: $10.18520 / \mathrm{cs} / \mathrm{v} 116 / 14 / 660-664$

\section{Modulation in activity profiles in insecticide-resistant population of tobacco caterpillar, Spodoptera litura (Fabricius)}

\author{
P. Sreelakshmi ${ }^{1, *}$, Thomas Biju Mathew ${ }^{1}$, \\ K. Umamaheswaran ${ }^{2}$ and A. Josephrajkumar ${ }^{3}$ \\ ${ }^{1}$ Department of Entomology, and \\ ${ }^{2}$ Department of Plant Pathology, College of Agriculture, Vellayani, \\ Thiruvananthapuram 695 522, India \\ ${ }^{3}$ ICAR-Central Plantation Crops Research Institute, \\ Kayankulam 690 533, India
}

Activity spectrum of detoxification enzymes was systematically assessed in tobacco caterpillar, Spodoptera litura collected from four locations in Kerala, India, to decipher the mechanism of insecticide resistance. Using the susceptible check ICAR-NBAIR strain, specific activity profiles of acetylcholine esterase (AChE) were found to be 16.16-, 10.71- and 4.88-fold higher in the Kovilnada, Palappur and Kanjikuzhi populations respectively. Specific activities of mixed function oxidase (MFO) were also found to be 19.24-, 17.11-, 6.08-fold higher in the same populations respectively, indicating the predominance of $\mathrm{AChE}$ and MFO towards imparting resistance. Carboxylesterase (CarE) and glutathion- $S$-transferase (GST) specific activity profiles were 3.62- and 3.37-fold higher in the Kovilnada population, followed by 2.89 - and 2.98 -fold higher in the Palappur population and as 2.10- and 1.15-fold higher in the Kanjikuzhi population, indicating their partial role in resistance development. Suppression of specific activities in synergism bioassays with $\mathrm{AChE}$ in chlorpyriphos + TPP treatment (9.32-fold), GST in chlorpyriphos + DEM (4.78-fold) and CarE in quinalphos + TPP (5.15-fold) highlighted the involvement of multiple detoxification enzymes conferring resistance to organophosphates. Reduced activity of MFO in case of lambda-cyhalothrin + PBO (5.35-fold), CarE in case of cypermethrin + TPP (7.36-fold) and 3.60-fold reduction in MFO in case of cypermethrin + PBO highlighted the role of esterases and MFOs towards resistance development against synthetic pyrethroids.

Keywords: Detoxification enzymes, insecticide resistance, Spodoptera litura, synergists.

INDISCRIMINATE use of insecticides targeting minor pests has resulted in their development as key pests by rapid gene alterations or physiological mechanisms which have provided these pests the capacity to tolerate toxic doses of insecticides. With the advancement in timeline, the number of insects known to be tolerant to various insecticides has also increased at an alarming rate. In 1986, 260 insect species were reported to have developed

*For correspondence. (e-mail: sreeagri108@gmail.com) 
resistance ${ }^{1}$. By the end of 2016, about 597 insects species of various orders had developed resistance at least one acaricide/insecticide. A total of 14,644 cases of arthropod insect resistance have been reported against 336 compounds throughout the world ${ }^{2}$.

Among the several insect pests that had developed resistance against various insecticides, Spodoptera litura (Lepidoptera: Noctuidae) is one whose management is mainly targeted by vigorous use of insecticides. S. litura is a polyphagous insect pest inflicting more than $26 \%$ $100 \%$ yield loss in South Asia ${ }^{3}$, and also resulting in significant economic loss to many economically important crops worldwide ${ }^{4}$. In order to reduce losses due to this pest, farmers often depended on chemical interventions involving organophosphates, carbamates, synthetic pyrethroids and some selected new-generation insecticides which resulted in the development of resistance and control failures $^{5,6}$. Key mechanisms behind this phenomenon were attributed to biochemical alterations, where detoxification enzymes play a vital role. Resistant strains of $S$. litura exhibited various resistance mechanisms such as reduced sensitivity of target sites ${ }^{7}$, enhanced metabolism of insecticides mediated by higher titres of detoxifying enzymes ${ }^{8}$ and reduced cuticular penetration.

The detoxifying enzymes associated with this metabolic resistance are carboxylesterase (CarE), glutathione- $S$ transferase (GST) and mixed function oxidase (MFO) ${ }^{8-10}$. These enzymes which generally occur in minute quantities in susceptible strains, lead to the development of resistant strains with their elevated levels making them capable of detoxification. On the other hand, synergists are considered as important additives in resistance management for disabling several metabolic mechanisms and are found to be viable options to bring back desensitized insecticides into functionality through alteration of detoxification enzymes ${ }^{11}$.

Considering the difficulty and cost involved in the formulation of new insecticide molecules, management of insecticide resistance is a dire need to upkeep the bioefficacy of present and future insecticides. In this context, it becomes vital to understand the probable mechanisms by which insects attain resistance so that we can wisely design strategies to counter the same.

The eggs and early instar larvae of $S$. litura were collected from the infested vegetable fields grown in test locations, viz. Kovilnada $\left(8^{\circ} 25^{\prime} \mathrm{N}, 77^{\circ} 21^{\prime} \mathrm{E}\right)$ and Palappur $\left(8^{\circ} 26^{\prime} \mathrm{N}, 76^{\circ} 58^{\prime} \mathrm{E}\right)$, Thiruvananthapuram district, Kerala, whose populations showed comparatively higher levels of resistance as well as Kanjikuzhi $\left(9^{\circ} 37^{\prime} \mathrm{N}, 76^{\circ} 20^{\prime} \mathrm{E}\right)$, Alappuzha district, Kerala (organic field check) along with susceptible reference strain of $S$. litura (Sblr) obtained from ICAR-National Bureau of Agricultural Insect Resources (NBAIR), Bengaluru, Karnataka. Bioassays were performed using this susceptible strain to obtain mortality data to be used as a reference for baseline susceptibility of insecticides. All populations were reared in separate containers in isolation under laboratory conditions and F1 generation from single egg mass was used for bioassays. Organic field check was selected based on discriminating dose concept ${ }^{12}$.

The susceptible Sblr strain was selected to evaluate and compare the levels of enzymes, viz. CarE, acetylcholine esterase (AChE), GST and MFO when exposed to test insecticides in combination with the synergists or devoid of them.

Commercial formulations of insecticides used in the bioassay were chlorpyriphos (Classic $20 \mathrm{EC}$, Cheminova), quinalphos (Ekalux $25 \mathrm{EC}$, Indofil Chemical Company Ltd, Mumbai), lambda cyhalothrin (Karate 5 EC, Syngenta India Ltd, New Delhi) and cypermethrin (Megahit 10 EC, Syngenta India Ltd, New Delhi). Enzyme activity was also evaluated in the presence of three synergists, viz. piperonyl butoxide (PBO; 3,4-methylenedioxy-6-propyl benzyl- $n$-butyl diethyleneglycolether); TCI Chemicals India Pvt Ltd, Chennai, diethyl maleate (DEM) and triphenyl phosphate (TPP; from Merck Life Sciences Pvt Ltd, Mumbai).

The technique for bioassay was adopted from the method described by the Insecticide Resistance Action Committee $^{13}$. Castor leaves were cut into discs of $5 \mathrm{~cm}$ diameter, rinsed thoroughly in distilled water and airdried to remove moisture followed by dipping in the test insecticide solution for about $25-30 \mathrm{sec}$. The excess insecticide solution was removed by gentle shaking of leaf discs. Ten early, third-instar larvae were transferred to each treated leaf forming one replication, and replicated thrice. For analysing the effect of synergist on insect enzyme levels, test insecticides were mixed with $\mathrm{PBO}$, DEM and TPP in the ratio $1: 4$ and bioassay was performed.

$S$. litura larvae (third instar) from selected locations and bioassay experiments were used for the study. Larvae representing each treatment were rinsed with acetone to remove surface residues and weighed. Whole larval homogenate was prepared by grinding seven larvae in an ice-bucket with sodium phosphate buffer $(100 \mathrm{mM}, \mathrm{pH}$ 7.0), containing $1 \mathrm{mM}$ each of EDTA (ethylene diamine tetra acetic acid), PMSF (phenyl methyl sulphonyl fluoride) and PTU (phenyl thiourea) and 20\% glycerol. Homogenate was centrifuged at $10,000 \mathrm{rpm}$ for $20 \mathrm{~min}$ at $4^{\circ} \mathrm{C}$. Pellet was thrown away while the supernatant was stored at $-20^{\circ} \mathrm{C}$ and used as enzyme source.

CarE activity was measured using the procedure of $\mathrm{Kranthi}^{12}$. The enzyme assay mixture consisted of $1 \mathrm{ml}$ enzyme stock and $5 \mathrm{ml}$ substrate solution incubated in the dark for $20 \mathrm{~min}$ at $30^{\circ} \mathrm{C}$, with intermittent shaking. A control blank was maintained separately with $1 \mathrm{ml}$ phosphate buffer and $5 \mathrm{ml}$ substrate solution. Next, $1 \mathrm{ml}$ each of staining solution was added to both the sample and blank tubes, and incubated again for $20 \mathrm{~min}$ at room temperature. Absorbance was recorded in double-beam UV spectrophotometer (Hitachi-U2900) at $590 \mathrm{~nm}$. 
AChE activity was measured using the procedure of Ellman et al. ${ }^{14}$. For the AChE enzyme assay, $100 \mu \mathrm{l}$ of enzyme stock was added to $2.86 \mathrm{ml}$ of sodium phosphate buffer followed by incubation at room temperature for $5 \mathrm{~min}$. Later, $10 \mu \mathrm{l}$ of 5,5-dithio-bis(2-nitrobenzoic acid) (DTNB) solution and $30 \mu \mathrm{l}$ of acetylcholine bromide were added. The change in absorbance was recorded at $412 \mathrm{~nm}$ for $30 \mathrm{~min}$ against blank. The AChE specific activity was expressed as $\mu \mathrm{mol}$ of acetylcholine hydrolysed $\mathrm{min}^{-1} \mathrm{mg}^{-1}$ protein.

GST activity was estimated using the methodology given by Kranthi ${ }^{13}$. Enzyme assay mixture consisted of $50 \mu \mathrm{l}$ of $50 \mathrm{mM}$ 1-chloro-2,4-dinitrobenzene (CDNB) and $150 \mu \mathrm{l}$ of $50 \mathrm{mM}$ reduced glutathione added to $2.77 \mathrm{ml}$ phosphate buffer containing $1 \mathrm{mM}$ EDTA and $1 \mathrm{mM}$ PTU. Next, $30 \mu \mathrm{l}$ of enzyme stock was added and the mixture was incubated at $25^{\circ} \mathrm{C}$ for $2-3 \mathrm{~min}$ after gentle shaking. Absorbance was read against the control blank without enzyme at $340 \mathrm{~nm}$ for $5 \mathrm{~min}$. Increase in absorbance over $5 \mathrm{~min}$ was used for calculation. Enzyme activity was estimated as CDNB-GSH conjugate formed in

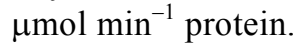

MFO activity was measured by modifying the methodologies given in the literature ${ }^{13,15,16}$. Enzyme assay mixture consisted of $760 \mu \mathrm{l}$ of phosphate buffer containing $1 \mathrm{ml}$ enzyme solution and $40 \mu \mathrm{l}$ of $p$-nitroanisole incubated at $34^{\circ} \mathrm{C}$ for $2 \mathrm{~min}$. The reaction was initiated by adding $200 \mu \mathrm{l}$ of nicotinamide adenine dinucleotide phosphate (NADPH). Change in absorbance was recorded at $405 \mathrm{~nm}$ at $15 \mathrm{sec}$ intervals for $20 \mathrm{~min}$, and specific activity was expressed in terms of nmol of $p$-nitrophenol formed $\mathrm{min}^{-1} \mathrm{mg}^{-1}$ protein.

Total soluble protein content was estimated according to the procedure described by Bradford ${ }^{17}$. One gram of test sample was homogenized in $10 \mathrm{ml}$ of $0.1 \mathrm{M}$ sodium acetate buffer ( $\mathrm{pH}$ 4.7) and centrifuged at $5000 \mathrm{~g}$ for $15 \mathrm{~min}$ at $4^{\circ} \mathrm{C}$. The supernatant was saved for estimation of soluble protein. The reaction mixture consisted of $0.5 \mathrm{ml}$ enzyme extract, $0.5 \mathrm{ml}$ distilled water and $5 \mathrm{ml}$ diluted (five times) dye solution. The absorbance was read at $595 \mathrm{~nm}$ using a spectrophotometer against reagent blank. Bovine serum albumin was used as the protein standard. The protein content was expressed as microgram albumin equivalent of soluble protein per gram on freshweight basis.

Table 1 shows the specific activities of detoxification enzymes to the feral populations of $S$. litura. The present study revealed that CarE specific activity was $1.086 \mu \mathrm{mol}$ of $\alpha$-naphthol formed $\mathrm{min}^{-1} \mathrm{mg}^{-1}$ protein in $S$. litura collected from Kovilnada, followed by Palappur $(0.866 \mu \mathrm{mol})$, Kanjikuzhi $(0.630 \mu \mathrm{mol})$ and ICAR-NBAIR $(0.300 \mu \mathrm{mol})$. Whereas AChE specific activity was found to be significantly higher with $2.263 \mathrm{nmol}$ of free thiol formed $\mathrm{min}^{-1}$ $\mathrm{mg}^{-1}$ protein in Kovilnada population, followed by $1.50 \mathrm{nmol}$ in Palappur, $0.683 \mathrm{nmol}$ in Kanjikuzhi and $0.14 \mathrm{nmol}$ in NBAIR strain. On the other hand, resistant population of $S$. litura collected from Kovilnada exhibited $1.046 \mu \mathrm{mol}$ of CDNB conjugated $\mathrm{min}^{-1} \mathrm{mg}^{-1}$ protein of GST activity followed by $S$. litura collected from Palappur $(0.923 \mu \mathrm{mol})$, Kanjikuzhi $(0.356 \mu \mathrm{mol})$, while that of NBAIR strain was only $0.31 \mu \mathrm{mol}$. Results also revealed that $S$. litura collected from Kovilnada showed very high specific activity of $141.78 \mathrm{nmol}$ of $p$-nitrophenol formed $\mathrm{min}^{-1} \mathrm{mg}^{-1}$ protein followed by those collected from Palappur (126.07 nmol) and Kanjikuzhi (44.80 nmol) compared to that of NBAIR $(7.37 \mathrm{nmol})$.

Table 2 presents results of biochemical tests on resistant populations of insect pests exposed to synergists. There was 9.32-fold reduction in specific activity of AChE in case of chlorpyriphos + PBO and 4.78-fold reduced specific activity of GST in case chlorpyriphos + DEM and 5.15-fold reduction in specific activity of CarF in case of quinalphos + TPP. This confirms the clear-cut role of multiple detoxifying enzymes such as esterases, MFOs and GSTs in imparting resistance against organophosphates. Whereas 7.33-fold reduced specific activity of AChE in case of lambda-cyhalothrin + TPP and 5.35fold reduced specific activity of MFO in case of lambdacyhalothrin $+\mathrm{PBO}$ and 7.36-fold reduced specific activity of CarE in case of cypermethrin + TPP and 3.60-fold reduction in $\mathrm{MFO}$ in case of cypermethrin $+\mathrm{PBO}$ confirm the role of esterases and MFOs in imparting resistance against synthetic pyrethroids.

In general, resistance towards insecticides is reported as either due to increase in the levels of detoxification enzymes or reduced target-site sensitivity ${ }^{18}$. Furthermore, insect metabolism has a pivotal role in the expression of resistance to insecticides. An earlier study had established resistance levels in S. litura populations collected from various parts of Kerala, against selected insecticides $^{19}$. In continuation, plausible mechanisms for resistance have been explored in the present study, and an intermediary association between CarE activity and organophosphate resistance was noticed. Esterases are frequently involved in the resistance of insects to organophosphate (OP) compounds, carbamates, and synthetic pyrethroids $^{20,21}$. Previous studies indicated a positive correlation of organophosphate insecticide resistance and increased CarE activity ${ }^{10,16,22}$, which is in agreement with our study. S. litura treated with sub-lethal doses of selected insecticides showed an increased specific activity of CarE in all cases and AChE in the case of organophosphates. Whereas reduction in levels AChE was noticed with pyrethroid treatment.

GSTs are another important set of detoxification enzymes whose activity mainly focuses on detoxification of organophosphates via conjugation ${ }^{23}$. The present work is in disparity with that of Cheema ${ }^{16}$, who reported only $0.447 \mu \mathrm{mol}$ of GST activity in resistant population of $S$. litura collected from Sangrur, Punjab. However, Karuppaiah et al. ${ }^{10}$ found $1.380 \mu \mathrm{mol}$ GST in S. litura collected from Varanasi and $1.155 \mu \mathrm{mol}$ in an insect population 


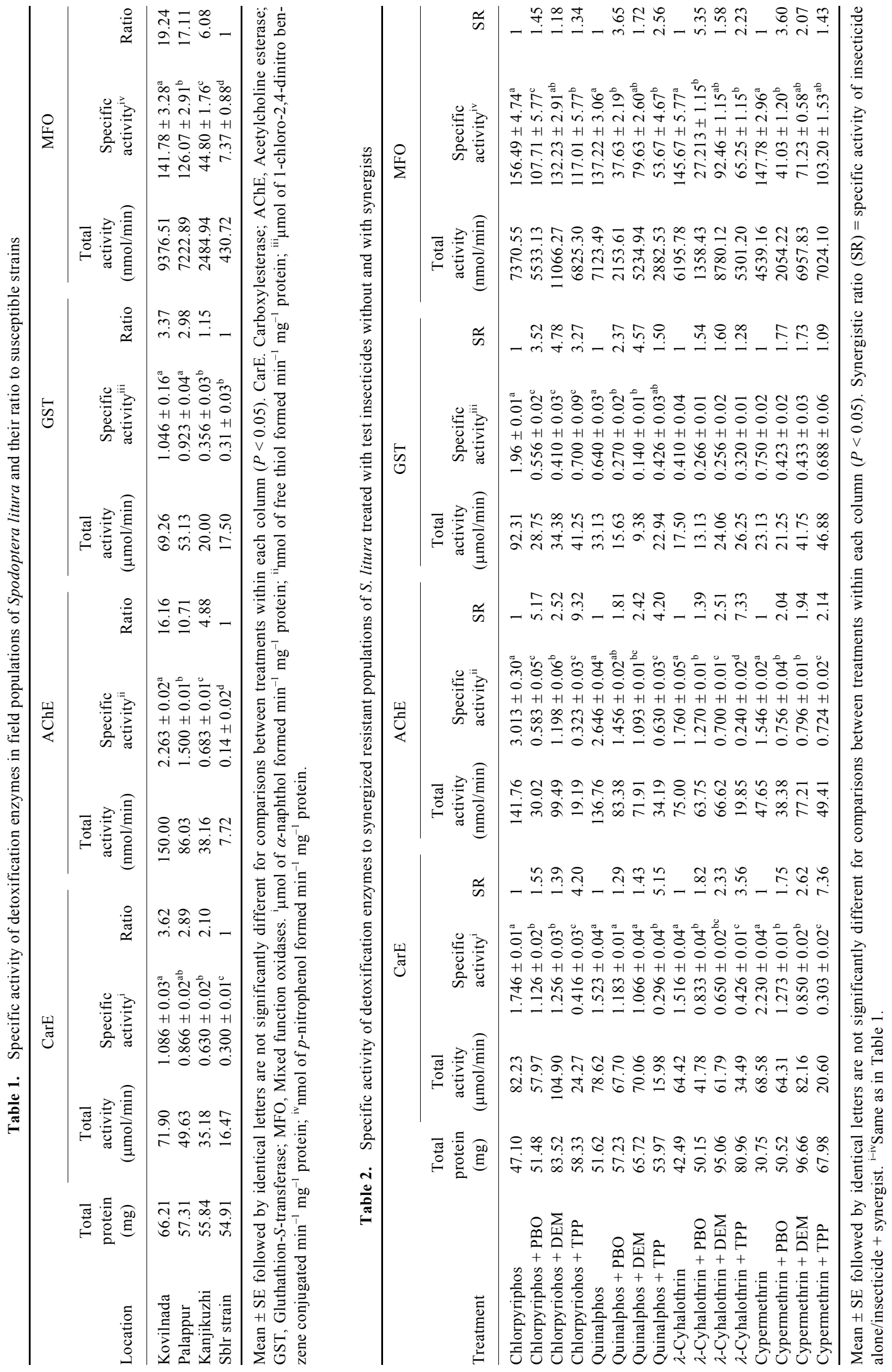




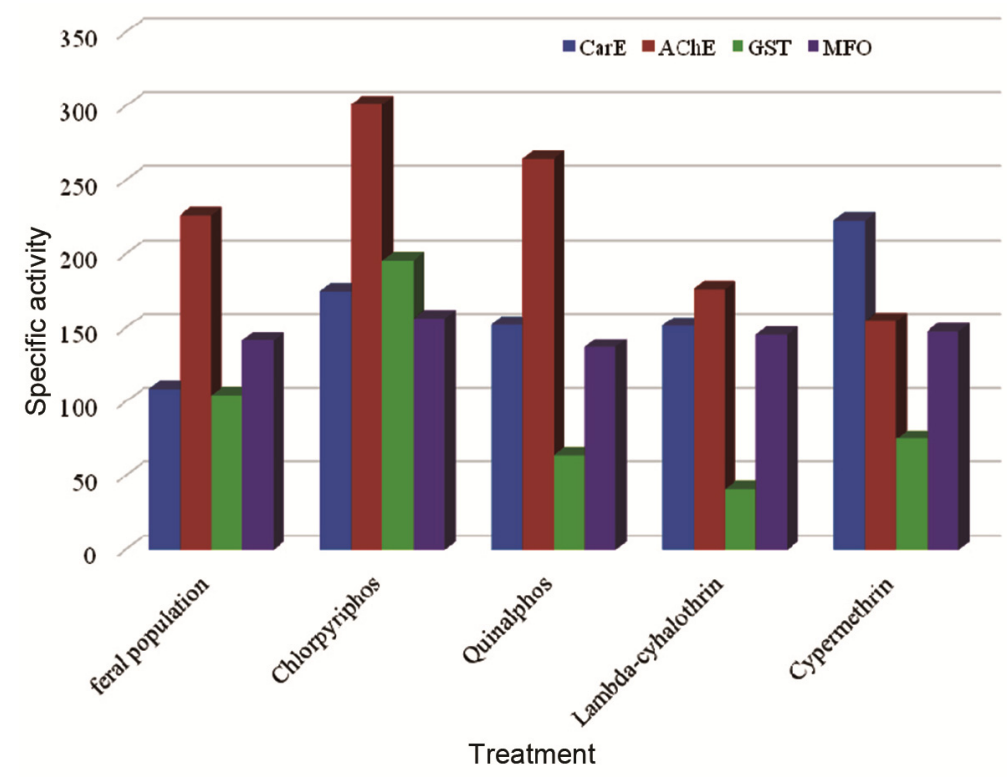

Figure 1. Variation in specific activity of detoxification enzymes after exposure to sub-lethal doses of insecticides.

collected from Delhi. MFOs are another set of detoxification enzymes with broad spectrum activity which may potentially affect the activity of several classes of insecticides $^{24}$. Higher MFO specific activity was observed in resistant populations of $S$. litura collected from Punjab ${ }^{16,22}$. Results of the present study were in conformity with those of Huang and $\mathrm{Han}^{8}$, and $\mathrm{Su}^{25}$, who had documented higher specific activity of MFO in resistant strains in comparison to susceptible strains of $S$. litura. The MFO specific activity can therefore be used as a biochemical indication for MFO-mediated resistance to pyrethroid in field-collected $S$. litura.

$S$. litura treated with sub-lethal doses of selected insecticides showed an increased specific activity of carboxyl esterases in all cases and of AChE in the case of organophosphates. Whereas reduction in the levels of AChE was noticed with pyrethroid treatment. Reduction in GST level was observed in all treatments, other than chlorpyriphos and increase in MFO was noticed in all treatments, other than quinalphos. This variation in enzyme levels after treatment with insecticides highlights the homeostasis mechanism exhibited by the insects via alteration of their enzyme levels. This mechanism triggers enzyme activities to counteract the xenobiotic exposed. Decreased sensitivity of AChE is reported as the most common mechanism of resistance development in insects to organophosphates. In the present study, an increase in detoxification enzyme activity was observed after treatment with selected insecticides at their sub-lethal concentrations (Figure 1). Yang et al. ${ }^{26}$ reported that a high esterase specific activity is normally correlated with development of resistance in insects. Findings of present experiment is in pact with the findings of Muthusamy et $a l^{27}$, who documented increased specific activities of CarE and AChE after treatment with lambda-cyhalothrin as well as increased GSH specific activity after treatment with dichlorovas at $10 \mathrm{ppm}$ concentration each. However, synergists can be effectively used in combination with susceptible insecticides to reduce the activity of detoxification enzymes, thereby breaking the resistance mechanisms.

The results of the present study are in concurrence with those of Armes et al. ${ }^{9}$, who reported that pre-treatment with $\mathrm{PBO}$ resulted in complete reduction of cypermethrin resistance (2-121-fold) in nearly all strains of $S$. litura, specifying that enhanced detoxification by MFOs was possibly the major mechanism against pyrethroids. They also reported that addition of the synergist DEF (S,S,Stributyl phosphorotrithioate), an inhibitor of esterases and the GST system, resulted in a 2-3-fold synergism with monocrotophos, indicating that esterases and GSTs are responsible to some extent for resistance towards organophosphates. In the present study, MFOs were found to play a crucial role in imparting resistance against synthetic pyrethroids. These results are agreement with the observations of Huang and $\mathrm{Han}^{8}$, who reported higher $\mathrm{PBO}$ synergism, which is an inhibitor of MFOs, to be associated with deltamethrin resistance in S. litura from China. The results of the present study are also in agreement with those of Sayyed et $a l^{28}$, who documented the involvement of MFOs and esterases in imparting resistance against synthetic pyrethroids in S. litura from Pakistan. Studies on synergistic effects of PBO and DEF reported that both monoxygenases and esterases may be involved in imparting resistance to pyrethroids in $S$. litura ${ }^{29,30}$. The results of present study were also in confirmation with those of our previous study on the efficacy of synergists in breaking the resistance, where piperonyl buetoxide was found to be highly effective towards organophosphates and synthetic pyrethroid resistance ${ }^{11}$. 


\section{RESEARCH COMMUNICATIONS}

Mechanisms of resistance may vary among populations from different locations. Insecticide resistance within or between chemical classes with similar modes of action is becoming an increasing problem in sustainable pest control. In the present study, elevated activities of MFO and esterase may be the probable cause of increase in resistance due to plausible cross-resistance mechanism between pyrethroids and AChE-targeted insecticides among $S$. litura populations from selected locations in Kerala. Synergism study could indicate their significance in decreasing resistance by inhibiting the resistance enzymes responsible and hence can be a useful tool in sustainable pest management programmes.

1. Brattsten, L. B., Potential role of plant allelochemicals in the development of insecticide resistance. In Novel Aspects of Insect Plant Interactions (eds Barbosa, P. and Letourneau, D. K.), Wiley, New York, 1986, pp. 313-348.

2. Arthropod pesticide resistance database, 2017; http://www pesticideresistance.com (accessed on 16 May 2017).

3. Dhir, B. C., Mohapatra, H. K. and Senapati, B., Assessment of crop loss in groundnut due to tobacco caterpillar, Spodoptera litura (F.). Indian J. Plant Prot., 1992, 20, 215-217.

4. Qin, H., Ye, Z., Huang, S., Ding, J. and Luo, R., The correlations of the different host plant with preference level, life duration and survival rate of Spodoptera litura Fabricius. Chin. J. Eco.-Agric., 2004, 12, 40-42. (Original not seen. Cited by Ahmad, M., Sayyed, A. H., Crickmore, N. and Saleem, M. A.). Pest Manage. Sci., 2007, 63, 1002-1010).

5. Abbas, N., Samiullah, Shad, S., Aslam, M., Razaq, M. and Waheed, A., Resistance of Spodoptera litura (Lepidoptera: Noctuidae) to profenofos: relative fitness and cross resistance. Crop Prot., 2014, 58, 49-54.

6. Saleem, M., Hussain, D., Ghouse, G., Abbas, M. and Fisher, S W., Monitoring of insecticide resistance in Spodoptera litura (Lepidoptera: Noctuidae) from four districts of Punjab, Pakistan to conventional and new chemistry insecticides. Crop Prot., 2016, 79, 177-184.

7. Yu, S. J., Insensitivity of acetylcholinesterase in a field strain of the fall armyworm, Spodoptera frugiperda (J. E. Smith). Pestic. Biochem. Physiol., 2006, 84, 135-142.

8. Huang, S. and Han, Z., Mechanisms for multiple resistance in field populations of common cutworm, Spodoptera litura (Fabricius) in China. Pestic. Biochem. Physiol., 2007, 87, 14-22.

9. Armes, N. J., Wightman, J. A., Jadhav, D. R. and Rao, G. V. R., Status of insecticide resistance in Spodoptera litura in Andhra Pradesh, India. Pestic. Manage. Sci., 1997, 50(3), 240-248.

10. Karuppaiah, V., Srivastava, C. and Subramanian, S., Variation in insecticide detoxification enzymes activity in Spodoptera litura (Fabricius) of different geographic origin. J. Entomol. Zool. Stud., 2017, 5(3), 770-773.

11. Sreelakshmi, P., Mathew, T. B., Josephrajkumar, A. and Paul, A. Synergist induced susceptibility of tobacco caterpillar, Spodoptera litura (Fabricius) from Kerala, India exposed to conventional insecticides. Phytoparasitica, 2018, 46, 97-104.

12. Kranthi, K. R., Insecticide Resistance-Monitoring, Mechanisms and Management Manual, Central Institute for Cotton Research, Nagpur, and ICAC, Washington, 2005, p. 150.

13. Insecticide Resistance Action Committee, 2014; http://www.iraconline.org (accessed on 18 November 2016).

14. Ellman, G. L., Courtney, K. D., Andres, V. and Featherstone, R. M., A new and rapid colorimetric determination of acetylcholinesterase activity. Biochem. Pharmacol., 1961, 7, 88-95.
15. Hansen, L. G. and Hodgson, E., Biochemical characteristics of insect microsomes: $\mathrm{N}$ - and O-demethylation. Biochem. Pharmacol., 1971, 20, 1569-1573.

16. Cheema, H. K., Evaluation of insecticide resistance profile in Spodoptera litura (Fabricius) populations through biological, biochemical and molecular diagnosis. PhD dissertation. Punjab Agricultural University, Ludhiana, 2013, p. 132.

17. Bradford, M. M., A rapid and sensitive method for the quantitation of microgram quantities of protein utilizing the principle of protein-dye binding. Anal. Biochem., 1976, 72, 248-254.

18. Feyereisen, R., Molecular biology of insecticide resistance. Toxicol. Lett., 1993, 82/83, 83-90.

19. Sreelakshmi, P., Mathew, T. B., Muralikrishna, P. and Paul, A., Insecticide resistance in field populations of tobacco caterpillar, Spodoptera litura Fabricius (Lepidoptera: Noctuidae). Entomon, 2017, 42(1), 41-46.

20. Hemingway, J. and Ranson, H., Insecticide resistance in insect vectors of human disease. Annu. Rev. Entomol., 2000, 45(1), 371391.

21. Srigiriraju, L., Semtner, P. J., Anderson, T. D. and Bloomquist, J. R., Esterase-based resistance in the tobacco-adapted form of the green peach aphid, Myzus persicae (Sulzer) (Hemiptera: Aphididae) in the eastern United States. Arch. Insect. Biochem. Physiol., 2009, 72(2), 105-123.

22. Kaur, P. and Kang, B. K., Effect of selected synergists on insecticidal toxicity of deltamethrin and biochemical mechanisms on the field populations of tobacco caterpillar from Punjab, India. Phytoparasitica $2015,43(4), 565-575$.

23. Rodriguez, M. A., Marques, T., Bosch, D. and Avilla, J., Assessment of insecticide resistance in eggs and neonate larvae of Cydia pomonella (Lepidoptera: Tortricidae). Pestic. Biochem. Physiol., 2011, 100, 151-159.

24. Scott, J. G., Cytochromes P450 and insecticide resistance. Insect Biochem. Mol. Biol., 1999, 29, 757-777.

25. Su, J., Lai, T. and Li, J., Susceptibility of field populations of Spodoptera litura (Fabricius) (Lepidoptera: Noctuidae) in China to chlorantraniliprole and the activities of detoxification enzymes. Crop Prot., 2012, 42, 217-222.

26. Yang, Y., Wu, Y., Chen, S., Devine, G. J., Denholm, I., Jewess, P. and Moores, G. D., The involvement of microsomal oxidases in pyrethroid resistance in Helicoverpa armigera from Asia. Insect Biochem. Mol. Biol., 2004, 34, 763-773.

27. Muthusamy, S., Shivakumar, M. S., Karthi, R. and Ramkumar, G., Pesticide detoxifiying mechanism in field population of Spodoptera litura (Lepidoptera: Noctuidae) from South India. Egypt. Acad. J. Biol. Sci., 2011, 3(1), 51-57.

28. Sayyed, A. H., Ahmad, M. and Saleem, M. A., Cross resistance and genetics of resistance to indoxacarb in Spodoptera litura (Lepidoptera: Noctuidae). J. Econ. Entomol., 2008, 101(2), 472479 .

29. Ahmad, M., Arif, M. I. and Ahmad, M., Occurrence of insecticide resistance in field populations of Spodoptera litura (Lepidoptera: Noctuidae) in Pakistan. Crop Prot., 2007, 26, 809-817.

30. Shad, S. A., Sayyed, A. H. and Saleem, M. A., Cross-resistance, mode of inheritance and stability of resistance to emamectin in Spodoptera litura Fab. (Lepidoptera: Noctuidae). Pest Manage. Sci., 2010, 66, 839-846.

ACKNOWLEDGEMENTS. We thank the Kerala Agricultural University, Thrissur for publication of part of Ph D (Agric) thesis work of the P.S. and the Department of Entomology, College of Agriculture, Vellayani, Thiruvananthapuram for providing the necessary facilities.

Received 4 June 2018; revised accepted 11 September 2018

doi: $10.18520 / \mathrm{cs} / \mathrm{v} 116 / \mathrm{i} 4 / 664-669$ 